\title{
Päivän pituuden ja valon laadun vaikutus Macrolophus-petoluteen kehitysnopeuteen ja lisääntymiseen
}

\author{
Anne Nissinen ${ }^{1}$, Delia Pinto ${ }^{1}$ ja Irene Vänninen ${ }^{1}$ \\ MTT Kasvintuotannon tutkimus, Animale, 31600 Jokioinen, anne.nissinen@mtt.fi
}

Pähkämöludetta (Macrolophus pygmaeus) käytetään Suomessa lähinnä ansarijauhiaisten torjuntaan kasvihuonetomaatilla. Talvikaudella, jolloin suurin osa valosta tuotetaan suurpainenatriumlampuilla (SPNL), luteiden lisääntymisessä on kuitenkin ollut ongelmia. Oletettiin, että valo-olosuhteet saattavat olla syynä huonoon lisääntymiseen, koska SPNL:n spektri poikkeaa päivänvalosta. Suomen ympärivuotisilla tomaattiviljelmillä päivänpituus on aina vähintään $16 \mathrm{~h}$ tekovalotuksen ansiosta. Välimeren alueelta kotoisin oleva ludelaji saattaa reagoida negatiivisesti näin pitkään päivään. Kolmen kasvatuskammiokokeen tavoitteena oli selvittää vaikuttaako päivän pituus tai valon laatu pähkämöluteen lisääntymiseen tai kehitysnopeuteen.

Ensimmäisessä kokeessa tutkittiin vain päivän pituuden vaikututusta käyttäen päivänvaloloisteputkia (PVLP). Toisessa kokeessa käytettiin SPNL:ja sekä SPNL:jen ja punaisten ledien yhdistelmää. Kolmannen kokeen tavoitteena on tutkia tarkemmin SPNL:illa tuotettujen päivänpituuksien vaikutusta luteisiin. Päivän pituudet (valoisat h:pimeät h) ensimmäisessä kokeessa olivat 16:8, 13:11, 11:13 ja 8:16 h, ja toisessa kokeessa 16:8 ja 11:8+5 valoa, jossa 5 h valojakson lopusta tuotettiin punaisella ledvalolla, koska oletettiin, että luteet eivät näe punaista. Kasvatuskammioissa luteet elivät yksittäin 9 cm:n petrimaljoilla ravintonaan jauhokoisan munia ja tupakanlehtikiekko, jolle ne myös munivat.

Ensimmäisen kokeen PVLP-kammioissa sekä naaras- että koirastoukat kehittyivät nopeimmin aikuisiksi 13:11 päivässä ja toisessa kokeessa 16:8 päivässä, jälleen PVL:1la valaistussa kammiossa. Ensimmäisessä kokeessa naaraat munivat elinaikanaan enemmän 8 ja 11 h:n päivässä kuin 16 h päivässä. Päivän pituus ei vaikuttanut naaraiden elinikään eikä toukiksi kuoriutuneiden munien määrään. Mikään päivänpituus ei siis aiheuttanut munadiapaussia. Toisessa kokeessa naaraat munivat elinaikanaan eniten $16 \mathrm{~h}$ valojaksossa, josta $11 \mathrm{~h}$ oli tuotettu SPNL:illa ja $5 \mathrm{~h}$ punaisilla ledeillä, mutta tilastollisesti ko. munamäärä oli sama kuin pelkillä SPNL:illa tuotetussa 16 h:n päivässä. Valon laatu (PVLP, SPNL, SPNL +led) ei vaikuttanut naaraiden elinikään. Kolmannessa kokeessa selvitetään vielä, vaikuttaako päivänpituus naaraiden elinikäiseen munamäärään myös SPNL:illa tuotetussa valossa.

Tulosten perusteella sekä päivän pituus että valon laatu vaikuttavat pähkömöluteen lisääntymiseen. SPNL:1la tuotettu 16 h:n päivä ei haittaa luteiden lisääntymistä, joten luteiden huonon lisääntymisen syyt ympärivuotisilla tomaattiviljelmillä ovat muualla. Osa SPNL:illa tuotetusta valojaksosta on korvattavissa punaisella led-valolla ilman haitallisia vaikutuksia pähkämöpetoluteen lisääntymiseen. Tällä tuloksella voi olla merkitystä jatkossa korvattaessa SPNL:illa tuotettua tekovaloa led-valoilla kasvihuoneiden energiankäytön pienentämiseksi, sillä luteiden toiminta ei häiriinny ainakaan punaisessa valossa.

Asiasanat: kasvinsuojelu, biologinen torjunta, luontainen vihollinen, Macrolophus, valojakso, valon laatu, lisääntyminen, tomaatti, ansarijauhiainen, 


\section{Johdanto}

Pähkämölude (Macrolophus pygmaeus) on 3,1-3,9 mm pitkä, yleisväritykseltään vihreä lude. Värityksestä erottuvat tummat tuntosarvien tyvijaokkeet ja silmien takana oleva tumma silmäjuova. Laji on paikoitellen yleinen Keski-Suomessa, jossa se esiintyy lehtopähkämöllä ja metsäkurjenpolvella (Rintala \& Rinne 2010). Macrolophus-luteet ovat petoja ja käyttävät ravinnokseen kirvoja, jauhiaisia, vihannespunkkeja ja miinaajakärpäsiä, joten niitä käytetään biologisina torjuntaeliöinä kasvihuoneissa (Perdikis \& Lykouressis 2000, Martinez-Cascales ym. 2006a, Perdikis ym. 2008). Ne pystyvät myös elämään käyttäen ravintonaan pelkästään kasvinesteitä (Perdikis \& Lykouressis 2000, Lykouressis ym. 2001, Perdikis \& Lykouressis 2004), joten ne saattavat aiheuttaa kasveille vioitusta, jos populaatiotiheydet ovat suuria ja saalista on vähän (Castañé ym. 2011). Macrolophus-suvun luteiden morfologiset erot ovat hyvin pieniä eivätkä värituntomerkit ole aina luotettavia (Perdikis ym. 2003, Martinez-Cascales ym. 2006a), joten lajien välisiä sekaannuksia on esiintynyt, ja pähkämöludetta on markkinoitu biologiseksi torjuntaeliöksi Macrolophus caliginosus-lajina (Martinez-Cascales ym. 2006b). Pähkämöludetta käytetään Suomessa lähinnä ansarijauhiaisten torjuntaan kasvihuonetomaatilla. Talvikaudella, jolloin suurin osa valosta tuotetaan suurpainenatriumlampuilla, luteiden lisääntymisessä on kuitenkin ollut ongelmia. Oletettiin, että valo-olosuhteet saattavat olla syynä huonoon lisääntymiseen, koska suurpainenatriumlamppujen spektri poikkeaa päivänvalosta. Suomen ympärivuotisilla tomaattiviljelmillä päivänpituus on aina vähintään $16 \mathrm{~h}$ tekovalotuksen ansiosta. Välimeren alueelta kotoisin oleva ludelaji saattaa reagoida negatiivisesti näin pitkään päivään. Kolmen kasvatuskammiokokeen tavoitteena oli selvittää, vaikuttaako päivän pituus tai valon laatu pähkämöluteen lisääntymiseen tai kehitysnopeuteen.

\section{Aineisto ja menetelmät}

Kokeissa käytettiin kaupallisesta lähteestä hankittua pähkämölude-kantaa (M. pygmaeus), joka toimitettiin nimellä $M$. caliginosus, mutta tunnistettiin myöhemmin $M$. pygmaeus-lajiksi. Pähkämöludekantaa lisättiin 16:8 h valojaksossa ennen kokeen aloittamista. Ensimmäisessä kokeessa tutkittiin vain päivän pituuden vaikututusta käyttäen valonlähteenä päivänvaloloisteputkia. Päivän pituudet (valoisat h:pimeät h) ensimmäisessä kokeessa olivat 16:8, 13:11, 11:13 ja 8:16 h. Toisessa kokeessa käytettiin suurpainenatriumlamppuja sekä niiden ja punaisten ledien yhdistelmää, sekä kontrollina päivänvaloloisteputkia. Päivän pituudet olivat 16:8 ja 11+5:8 valoa, jossa 5 h valojakson lopusta tuotettiin punaisella led-valolla, koska oletettiin, että nämä hyönteiset eivät näe punaista. Suurpainenatriumlamppujen ja punaisten ledien yhdistelmäkäsittely toistettiin kahdessa kammiossa. Kummassakin kokeessa lämpötila kammioissa oli asetettu 25 asteeseen ja kosteus 70 prosenttiin. Ensimmäisessä kokeessa luteita oli $32 \mathrm{kpl}$ kussakin käsittelyssä ja toisessa kokeessa $28 \mathrm{kpl}$. Kasvatuskammioissa luteet kasvatettiin yksittäin $9 \mathrm{~cm}: n$ petrimaljoilla ravintonaan jauhokoisan munia ja tupakanlehtikiekko, jolle ne myös munivat. Sekä toukat että aikuiset ruokittiin joka toinen päivä ja lehtikiekko vaihdettiin uuteen 4 päivän välein. Ensin mitattiin toukkakehitysaika, sen jälkeen naaraiden elinikäinen munatuotanto (fekunditeetti) sekä naaraiden elinikä, lopuksi vielä munien kuoriutumisprosentti. Kolmannessa, käynnissä olevassa kokeessa tutkitaan, vaikuttaako päivänpituus naaraiden elinikäiseen munamäärään myös suurpainenatriumlampuilla tuotetussa valossa.

\section{Tulokset ja tulosten tarkastelu}


Pelkästään päivänvaloloisteputkia käytettäessä sekä naaras- että koirastoukat kehittyivät nopeimmin aikuisiksi 13:11 päivässä. Toisessa kokeessa toukat kehittyivät nopeimmin 16:8 päivässä, jälleen päivänvaloloisteputkilla valaistussa kammiossa, mutta tässä kokeessa ei ollut lyhyempiä päivänpituuksia mukana. Ensimmäisessä kokeessa naaraat munivat elinaikanaan enemmän 8 ja 11 tunnin päivässä kuin $16 \mathrm{~h}$ päivässä. Päivän pituus ei vaikuttanut naaraiden elinikään eikä toukiksi kuoriutuneiden munien määrään. Mikään päivänpituus ei siis aiheuttanut munadiapaussia. Toisessa kokeessa naaraat munivat elinaikanaan eniten $16 \mathrm{~h}$ valojaksossa, josta $11 \mathrm{~h}$ oli tuotettu suurpainenatriumlampuilla ja $5 \mathrm{~h}$ punaisilla ledeillä, mutta munamäärä ei poikennut pelkästään suurpainenatriumlampuilla tuotetussa 16 tunnin päivässä. Valon laatu ei vaikuttanut naaraiden elinikään.

Tulosten perusteella sekä päivän pituus että valon laatu vaikuttavat pähkömöluteen lisääntymiseen. Suurpainenatriumlamppujen valo on pähkämöluteen muninnan kannalta parempaa kuin päivänvaloloisteputkien valo. Ympärivuotisten tomaattiviljelmien käyttämä 16 tunnin päivä, joka on tuotettu suurpainenatriumlamppujen avulla, ei näytä haittaavan luteiden lisääntymistä, joten luteiden huonon lisääntymisen syyt saattavat olla esimerkiksi erilaisissa viljelylämpötiloissa kesä- ja talvikaudella. Aiemmissa tutkimuksissa on todettu, että optimilämpötila pähkämöluteen toukkakehitykselle on 27,5-30 astetta (Perdikis \& Lykouressis 2000). Pähkämöluteen saalistustehokkuus kasvaa lämpötilan noustessa (Perdikis ym. 2004), mutta toisaalta luteet saalistivat eniten pimeäjakson aikana (Perdikis ym. 2004). Vaikka luteet näyttävät lisääntyvän hyvin pitkässä päivässä, niiden saalistusteho saattaa jäädä alhaisemmaksi, mikä puolestaan voi vaikuttaa ansarijauhiaisten lisääntymiseen. Päivän pituuden vaikutus saalistustehokkuuteen ei kuitenkaan selitä pähkämöluteen heikkoa lisääntymistä talvikaudella, koska kesällä päivän pituus on suurempi kuin talvella keinovalotetuissa kasvustoissa. Macrolophus-lajeilla on varsin kapea isäntäkasvispesifisyys (Martinez-Cascales ym. 2006a), mikä saattaa myös vaikuttaa luteiden asettumiseen kasvihuoneessa, mikäli kaupallisesti saatavissa oleva laji vaihtelee esim. tuottajan mukaan. Ei ole myöskään tiedossa, reagoivatko luteet luonnonvalon määrään talvikaudella, sillä toisin kuin kasvatuskammiossa, kasvihuoneissa ne altistuvat myös luontaiselle päivänpituuden vaihtelulle huolimatta tekovalotuksesta.

Pähkämöluteet näyttäisivät pystyvän aistimaan punaisen valon valona, koska naaraiden keskimääräinen elinikäinen munamäärä $11+5: 8$ päivänpituudessa ei eronnut pelkästään suurpainenatriumlampuilla tuotetusta 16 tunnin päivänpituuskäsittelystä. Aiemmin on oletettu, että luteet eivät näkisi punaista valoa, esimerkiksi Gemeno ym. (2007) käyttivät punaista valoa tutkiessaan Macrolophus caliginosus-lajin parittelukäyttäytymistä "pimeässä". Mauriaisten on osoitettu käyttäytyvän eri tavalla punaisessa valossa kuin pimeässä, vaikka aiemmin oletettiin, että muurahaiset eivät näe punaista valoa (Depickère ym. 2004). Punaisen valon aistimismekanismit hyönteisillä tunnetaan edelleen puutteellisesti, ja on ehdotettu esim. värisokeaa mekanismia, joka hyödyntäisi muille aallonpituuksille herkkiä fotoreseptoreita (Reisenman ym. 2000).

Kokeiden perusteella näyttää, että osa suurpainenatriumlampuilla tuotetusta valojaksosta on korvattavissa punaisella led-valolla ilman haitallisia vaikutuksia pähkämöluteen lisääntymiseen. Tällä tuloksella voi olla merkitystä jatkossa kasvihuoneiden energiankäytön pienentämisessä, sillä ledvalojen sähkönkulutus on alhaisempi ja käyttöikä pitempi kuin suurpainenatriumlampuilla (Morrow 2008).

\section{Johtopäätökset}

Tulosten perusteella sekä päivän pituus että valon laatu vaikuttavat pähkömöluteen lisääntymiseen. Suurpainenatriumlampuilla tuotettu 16 tunnin päivä ei haittaa luteiden lisääntymistä, joten luteiden huonon lisääntymisen syyt ympärivuotisilla tomaattiviljelmillä ovat muualla. Osa suurpainenatriumlampuilla tuotetusta valojaksosta on korvattavissa punaisella led-valolla ilman 
haitallisia vaikutuksia pähkämöpetoluteen lisääntymiseen. Tällä tuloksella voi olla merkitystä jatkossa kasvihuoneiden energiankäytön vähentämisen kannalta.

\section{Kirjallisuus:}

Castañé, C., Arnó, J., Cabarra, R. \& Alomar, O. 2011. Plant damage to vegetable crops by zoophytophagous mirid predators. Biological Control 59: 22-29.

Depickère, S., Fresneau, D., Deneubourg, J. L. 2004. The influence of red light on the aggregation of two castes of the ant, Lasius niger. Journal of Insect Physiology 50: 629-635.

Gemeno, C., Alomar, O., Ruidavets, J. \& Castañé, C. 2007. Mating periodicity and post-mating refractory period in the zoophytophagous plant bug Macrolophus caliginosus (Heteroptera: Miridae). European Journal of Entomology 104: 715-720.

Lykouressis, D., Perdikis, D. \& Michalaki, M. 2001. Nymphal development and survival of Macrolophus pygmaeus Rambur (Hemiptera: Miridae) on two eggplant varieties as affected by temperature and presence/absence of prey. Biological Control 20: 222-227.

Martinez-Cascales, J.I., Cenis, J.L., Cassis, G. \& Sanchez, J.A. 2006a. Species identity of Macrolophus melanotoma (Costa 1853) and Macrolophus pygmaeus (Rambur 1839) (Insecta: Heteroptera: Miridae) based on morphological and molecular data and bionomic implications. Insect Systematics \& Evolution 37(4): 385-404.

Martinez-Cascales, J.I., Cenis, J.L. \& Sanchez, J.A. 2006b. Differentiation of Macrolophus pygmaeus

(Rambur 1839) and Macrolophus melanotoma (Costa 1853) (Heteroptera: Miridae) based on molecular data.

IOBC/WPRS Bulletin 29 (4): 223-228.

Morrow, R.C. 2008. LED lighting in horticulture. HortScience 43 (7): 1947-1950.

Perdikis, D., Kapaxidi, E. \& Papadoulis, G. 2008. Biological control of insect and mite pests in greenhouse

Solanaceous crops. The European Journal of Plant Science and Biotechnology 2 (Special Issue 1): 125-144.

Perdikis, D. C. \& Lykouressis, D. P. 2000. Effect of various items, host plants, and temperatures on the development and survival of Macrolophus pygmaeus Rambur (Hemiptera: Miridae). Biological Control 17: 5560 .

Perdikis, D. C. \& Lykouressis, D. P. 2004. Macrolophus pygmaeus (Hemiptera: Miridae) population parameters and biological characteristics when feeding on eggplant and tomato without prey. Journal of Economic Entomology 97 (4): 1291-1298.

Perdikis, D. C., Lykouressis, D. P. \& Econoumou, L. P. 2004. Influence of light-dark phase, host plant, temperature, and their interactions on the predation rate in an insect predator. Environmental Entomology 33 (5): 1137-1144.

Perdikis, D. C., Margaritopoulos, J. T., Stamatis, C., Mamuris, Z. Lykouressis, D. P., Tsitsipis, J. A. \& Pekas, A. 2003. Discrimination of the closely related biocontrol agents Macrolophus melanotoma (Hemiptera: Miridae) and M. pygmaeus using mitochondrial DNA analysis. Bulletin of Entomological Research 93: 507-514. Reisenman, C.E., Figueiras, A. N. L., Giurfa, M. Lazzari, C.R. 2000. Interaction of visual and olfactory cues in the aggregation behaviour of the haematophagous bug Triatoma infestans. Journal of Comparative Physiology A 186: 961-968.

Rintala, T. \& Rinne, V. 2010. Suomen luteet. Hyönteistarvike TIBIALE Oy, Helsinki. 352 s. 